\title{
C:
}

\section{First Records of Albinism or Leucism in Six Species of Snakes from Central India}

Rahul V. Deshmukh ${ }^{1}$, Sagar A. Deshmukh ${ }^{1,2}$, Swapnil A. Badhekar ${ }^{1,3}$, Jagdish Rewatkar ${ }^{4}$, Vijay P. Pachare ${ }^{4,5}$, and Sujit B. Kawale ${ }^{4,5}$

\author{
${ }^{1}$ Ward No. 4, Teacher Colony, Kalmeshwar Brahmani, Nagpur, Maharashtra-441501, India (rahul30.snake@gmail.com) \\ ${ }^{2}$ Kalmeshwar Brahmani, Nagpur, Maharashtra-441501, India (sd.snakefriend@gmail.com) \\ ${ }^{3}$ Tiwaskarwadi, Raipur, Hingana, Nagpur, Maharashtra-441110, India (swapnilbadhekar86@gmail.com) \\ ${ }^{4}$ Teacher Colony, Paras, Akola, Maharashtra-444109, India (jagdishrewatkar1@gmail.com) \\ ${ }^{5}$ Rajura District, Chandrapur, Maharashtra, India (Vijay.pachare@gmail.com) (sujitkawale22@gmail.com)
}

B oth albinism and leucism have been described in reptiles (e.g., Bechtel 1995; Broghammer 2000). Albinism is the absence of both integumentary and retinal pigmentation, which results in a white or yellowish body and red eyes. Leucism, sometimes considered a form of incomplete albinism involving reduced or absent integumentary pig- mentation with retention of color in the eyes, is expressed as complete or partial integumentary pigmentation and dark eyes. Coloration plays an important role in predator avoidance through crypsis, mimicry, or aposematism (e.g., Sweet $1985)$ and also in inter- and intraspecific communication and sexual selection (e.g., Roulin and Bize 2006). Consequently,
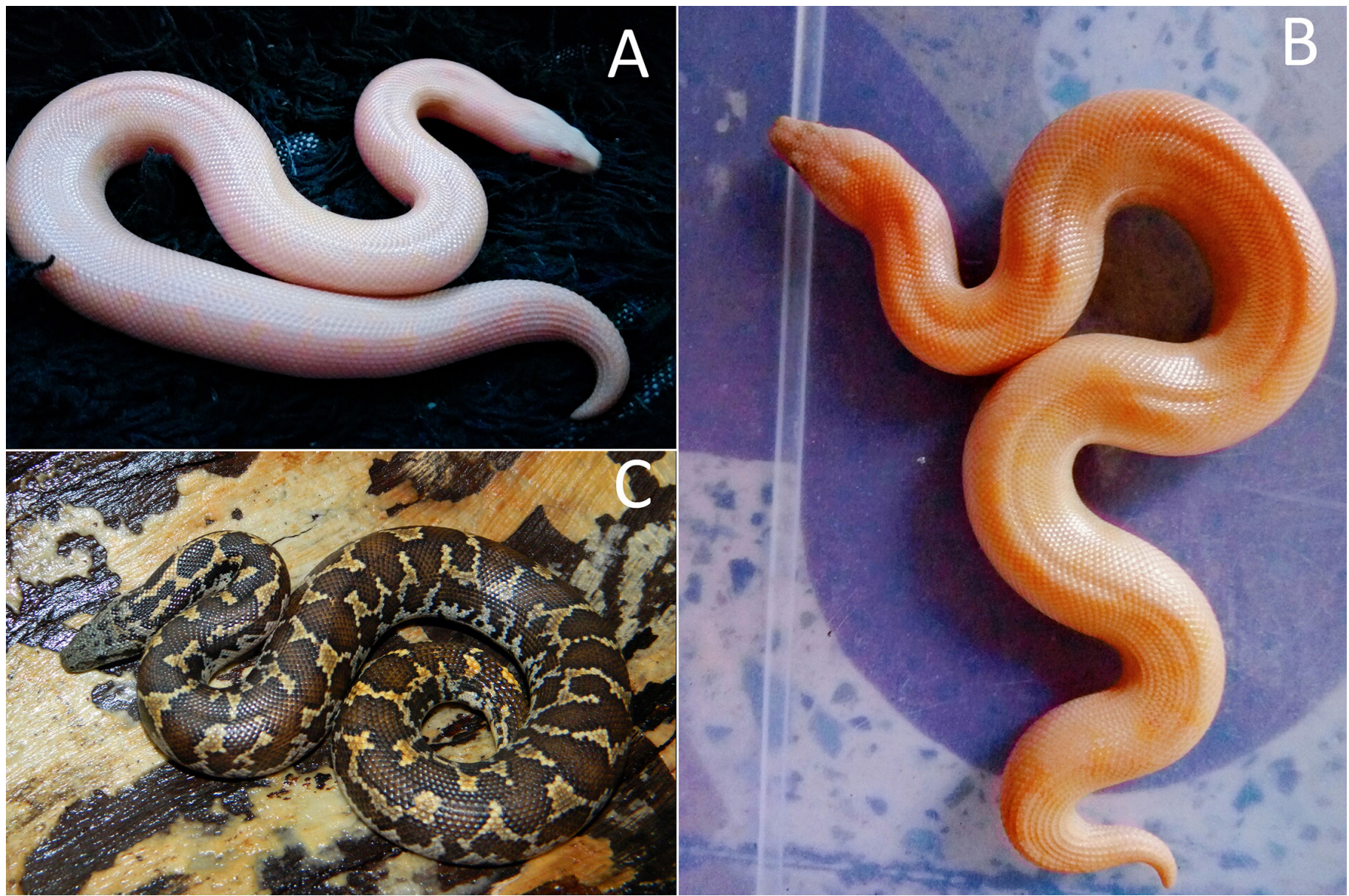

Fig. 1. (A/B) An albino juvenile Common Sand Boa/Rough-tailed Sand Boa (Eryx conicus). (C) Typically colored juvenile. Photographs by Jagdish Rewatkar (A \& B) and Sagar Deshmukh (C). 
both of these forms of aberrant coloration are rare in nature because albinistic or leucistic individuals rarely survive and reproduce (e.g., Bechtel and Bechtel 1981; Krecsák 2008). In addition, albinos have sun-sensitive skin, which can affect growth (Spodola and Ditoro 2007), and often have impaired vision (e.g., Creel et al. 1990). Bechtel (1995) estimated that the ratio of albinism in wild vertebrates was $1: 10,000$ to 1:30,000. Previous studies documenting instances of leucism or albinism in Indian reptiles in general and snakes in particular include Lahiri (1955), Whitaker (1971), Kumar (1988), Basu et al. (2003), Cyril (2009), Sayyed (2012), Vyas (2012, 2013), Vyas et al. (2012), Hoshing et al. (2013), Bhutkar and Mahabal (2014), Jadhav et al. (2014), Adimallaah and Vyas (2015), Kumbar et al. (2016), and Thakur and Trivedi (2018). Also, Mahabal and Thakur (2014) provided a comprehensive report on aberrant coloration and patterns in the Indian herpetofauna. Herein we report first records of leucism or albinism for six species of snakes from Central India.

Common Sand Boa/Rough-tailed Sand Boa, Eryx conicus (Schneider 1801). These stout-bodied, medium-sized snakes with strongly keeled scales are abundant in arid localities throughout the Indian Subcontinent, including Pakistan, Nepal, Sri Lanka, and Bangladesh, but excluding the Andaman and Nicobar Islands (Das 2002; Whitaker and Captain 2004). Although mostly crepuscular or nocturnal (Das 2002), these snakes are known to hunt by day (Whitaker and Captain 2004). They are strong burrowers in loose sand or silty soil (Sharma 2007) and generally constrict prey, which includes small mammals, birds, reptiles, amphibians, and even large insects (Smith 1943; Das 2002; Sharma 2007; Whitaker and Captain 2004).
At 0710 h on 8 July 2018, at the Thermal Power Station, Paras, Balapur, Akola, Maharashtra, India $\left(20.716537^{\circ} \mathrm{N}\right.$, $76.796762^{\circ} \mathrm{E}$ ), Jagdish Rewatkar rescued an albino juvenile Common Sand Boa $(-150 \mathrm{~mm}$ total length) that was basking on a rocky trail. The snake was pale pink with red eyes (Fig. 1). It was released into appropriate habitat.

\section{Green Keelback/Lead Keelback, Rhabdophis plumbicolor} (Cantor 1839). These snakes are distributed throughout India, except along the eastern coast, the Ganges Valley, and the extreme northeastern parts of the country, and are commonly encountered in some areas of Maharashtra (Whitaker and Captain 2004; Deshmukh et al. 2015). They occur mainly in hills at elevations of 600-1,800 m (Daniel 2002).

During a rescue operation at $1810 \mathrm{~h}$ on 6 August 2014 in the Shri Residential Colony near Bhagatwadi, Paras, TahsilBalapur, Akola District, Maharashtra, India $\left(20.050889^{\circ} \mathrm{N}\right.$, $\left.73.713797^{\circ} \mathrm{E}\right)$, Jagdish Rewatkar rescued a young, unsexed, leucistic Green Keelback ( $-300 \mathrm{~mm}$ SVL) that was yellowish in color with a light greenish remnant of a mark on the nape, and reddish eyes (Fig. 2). It was released into suitable habitat near the site of collection.

\section{Checkered Keelback/Asiatic Watersnake, Fowlea pisca-} tor (Schneider 1799). These snakes are among the most frequently encountered aquatic snakes and possibly the most plentiful species of snake in India (Whitaker and Captain 2005). They inhabit the whole of India to Baluchistan and the northwestern frontier provinces and extend into the IndoChinese region as far east as Myitkina in upper Burma (Smith 1943). They are very common in central India (Nande and Deshmukh 2007; Deshmukh et al. 2015), where they occur

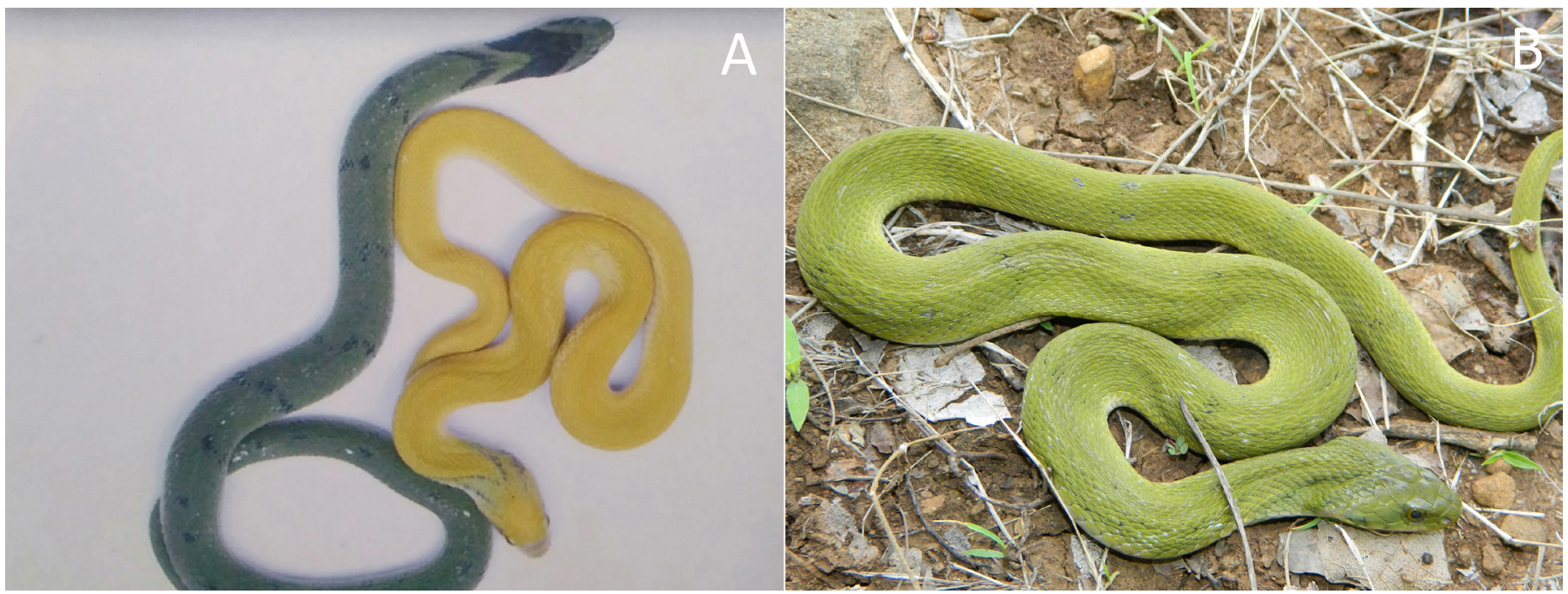

Fig. 2. (A) Leucistic and typically colored Green Keelback/Lead Keelback (Rhabdophis plumbicolor). (B) Typically colored aduult. Photographs by Jagdish Rewatkar (A) and Sagar Deshmukh (B). 


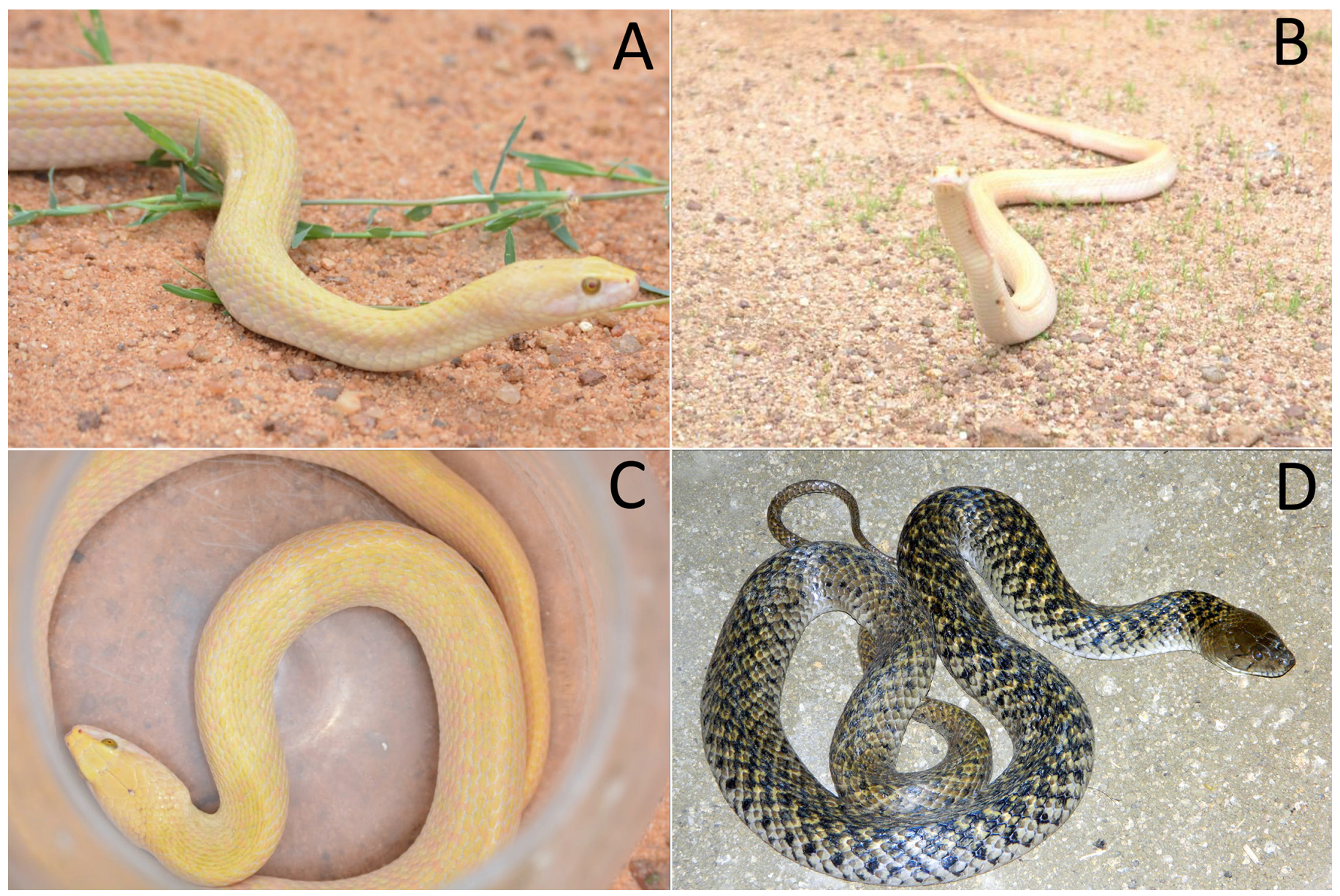

Fig. 3. (A/B/C) Albino Checkered Keelback/Asiatic Watersnake (Xenochrophis piscator). (D) Typically colored adult. Photographs by Vijay Pachare (A \& B), Sujit Kawale (C), and Sagar Deshmukh (D).

in and around rivers, ponds, and paddy fields. Extremely active, these snakes are capable of jumping off the ground, and in water they swim nimbly and are capable divers (Daniel 2002). They feed on frog eggs, tadpoles, frogs, fish, and occasionally on rodents and birds (Whitaker and Captain 2005).

Vijay Pachare and Sujit Kawale observed a male albino at $2155 \mathrm{~h}$ on 12 June 2017 in a small tank at the Sajid Cement Work Factory in Chunala, Rajura, Chandrapur District,
Maharashtra, India $\left(19.789099^{\circ} \mathrm{N}, 79.395534^{\circ} \mathrm{E}\right)$. It was active and aggressive. The adult snake (705 $\mathrm{mm} \mathrm{SVL)} \mathrm{had} \mathrm{a}$ yellowish body without the usual checkered pattern and greenish eyes with a reddish pupil (Fig. 3). It was released near a natural pond in a nearby forest in Chunala, Rajura, Chandrapur.

Indian Wolf Snake/Common Wolf Snake, Lycodon aulicus (Linnaeus 1758). These snakes occur throughout India
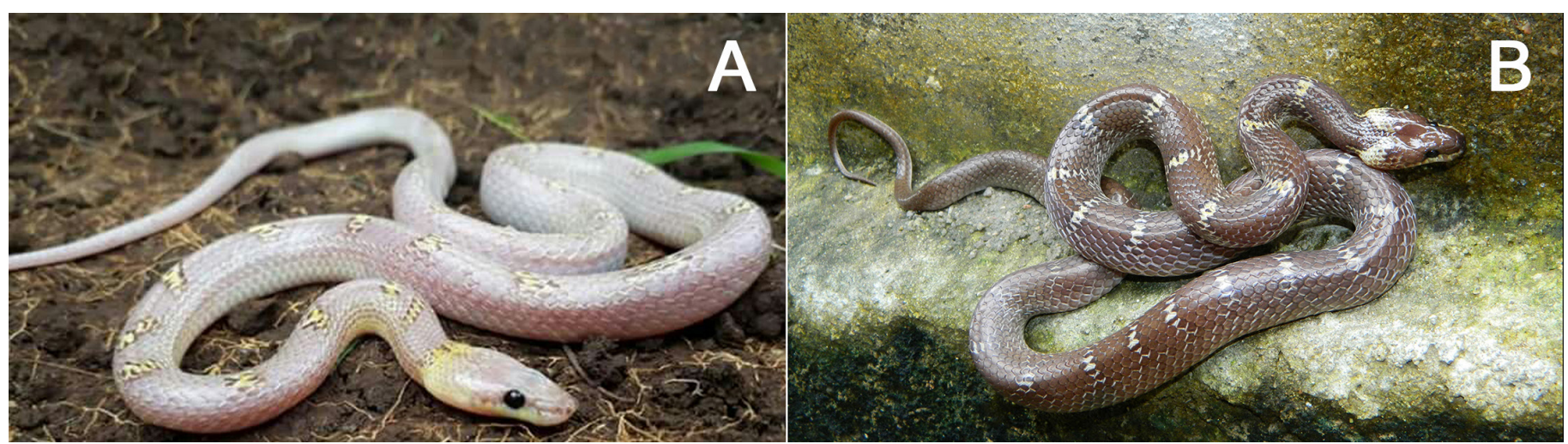

Fig. 4. (A) Leucistic Indian Wolf Snake/Common Wolf Snake (Lycodon aulicus). (B) Typically colored individual. Photographs byJagdish Rewatkar (A) and Sagar Deshmukh (B). 

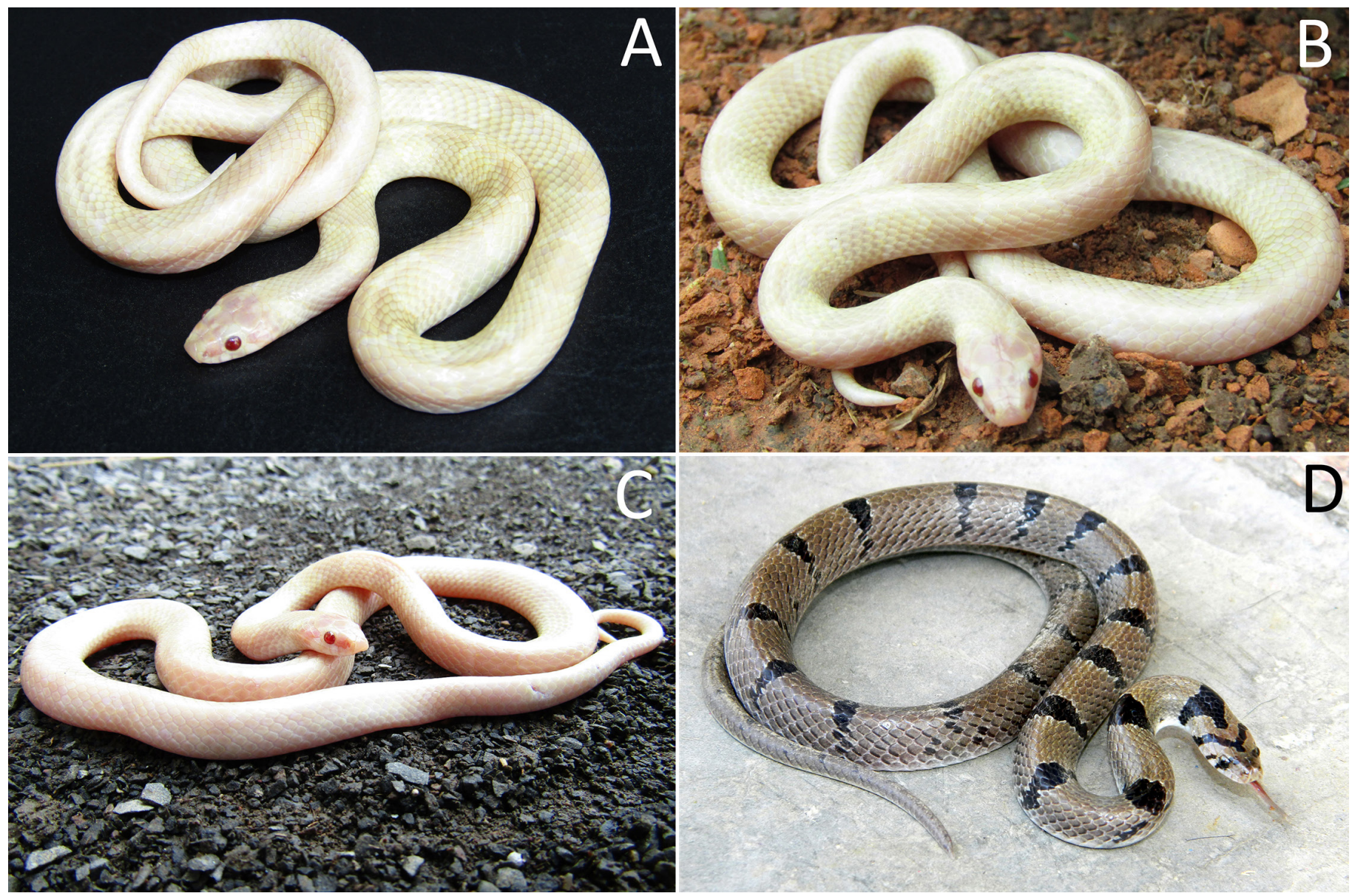

Fig. 5. (A/B/C) Common Kukri Snake/Banded Kukri Snake/Russet Kukri Snake (Oligodon arnensis). (D) Typically colored snake. Photographs by Jagdish Rewatkar (ABC) andSagar Deshmukh (D).

(including Lakshadweep but not the Andaman and Nicobar Islands (Whitaker and Captain 2004). One of the most frequently encountered snakes of the Indian plains and very common in the Nagpur Region of central India (Deshmukh et al. 2015), they are strictly nocturnal and often occur near and in human habitations (Daniel 2002).

Jagdish Rewatkar observed a leucistic individual at 2205 h on 3 August 2018 at the VBH Colony in Paras, Akola, Maharashtra, India $\left(20.680199^{\circ} \mathrm{N}, 77.034660^{\circ} \mathrm{E}\right)$. Coloration of the body was pinkish with normally colored yellowish bands (Fig. 4). It was released in an abandoned building.

\section{Common Kukri Snake/Banded Kukri Snake/Russet} Kukri Snake, Oligodon arnensis (Shaw 1802). This species occurs throughout India (except the Andaman and Nicobar Islands and possibly the extreme northeastern parts of the country) and also is found in Pakistan, Nepal, Bangladesh, and Sri Lanka (Whitaker and Captain 2004). These active little snakes are mainly diurnal and most frequently encountered during the rainy season (Daniel 2002).
During a rescue operation at $2050 \mathrm{~h}$ on 12 June 2017 , an albino was crossing a road next to railway track in the Panchsheel Nagar Railway Station, Paras, Balapur, Akola, Maharashtra, India $\left(20.729010^{\circ} \mathrm{N}, 77.013809^{\circ} \mathrm{E}\right)$. The unsexed snake (350 mm SVL) had a faint pinkish-brown body and red eyes (Fig. 5). It was released into appropriate habitat on the outskirts of Akola City.

\section{Common Indian Krait, Bungarus caeruleus (Schneider} 1801). These venomous snakes occur throughout India and also are known from Afghanistan, Pakistan, Sri Lanka, Bangladesh, and Nepal. Kraits are nocturnal and are known to feed on snakes (even other kraits) as well as rodents, lizards, and frogs (Whitaker and Captain 2008). They are common in the Nagpur District (Deshmukh et al. 2015).

At 1945 h on 13 October 2017, Jagdish Rewatkar encountered an unsexed adult albino $(-610 \mathrm{~mm})$ near the Saraswati High School, Paras, Balapur, Akola, Maharashtra, India $\left(20.719253^{\circ} \mathrm{N}, 76.816279^{\circ} \mathrm{E}\right)$. The body was yellowish-white with white bands and its eyes were red (Fig. 6). The snake was released at the site of capture. 

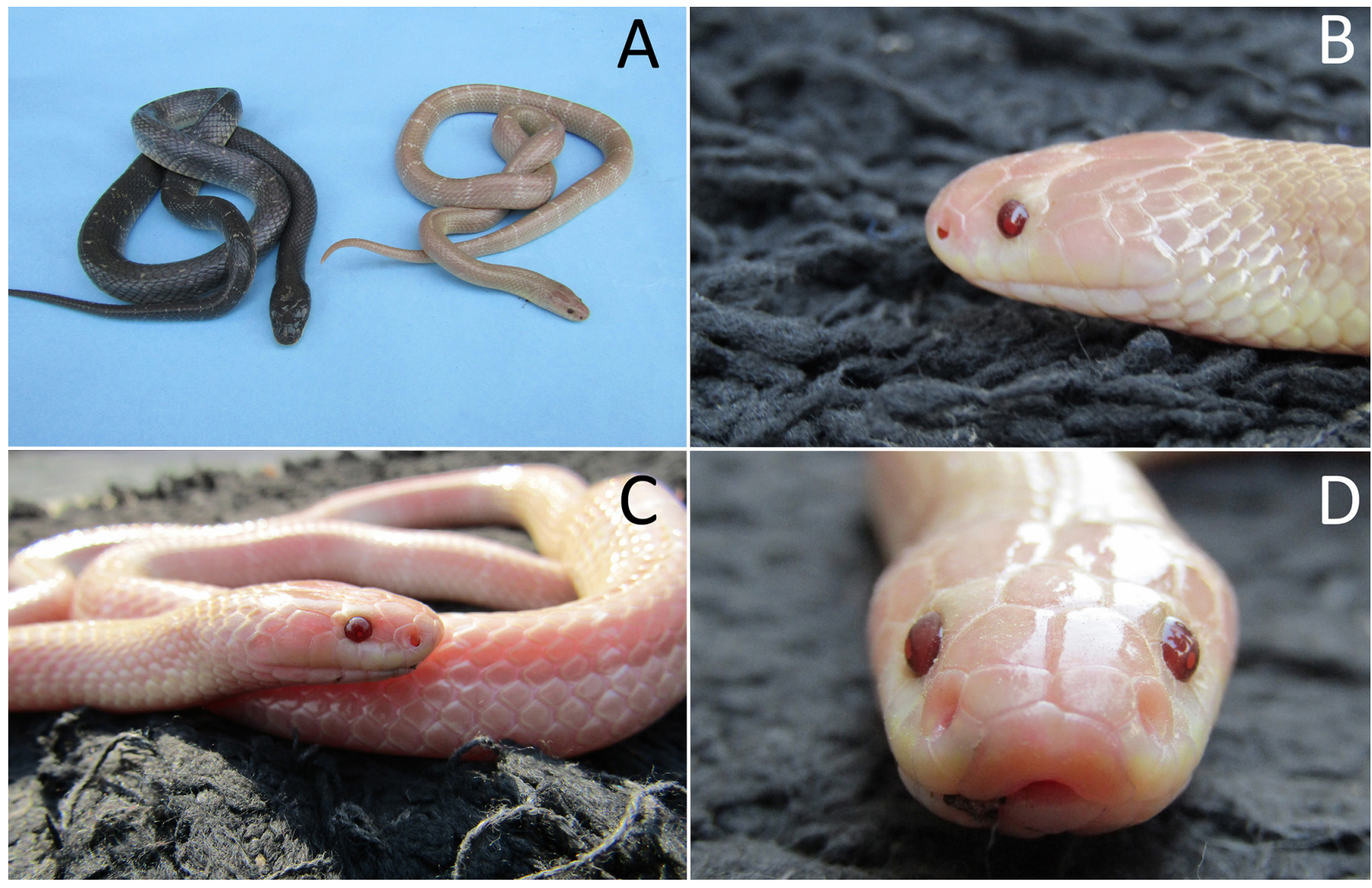

Fig. 6. (A) Albino and typically colored Common Indian Krait (Bungaeus caeruleus). (B/C/D) Albino showing the red eye. Photographs by Jagdish Rewatkar

\section{Acknowledgements}

Subham Katgube, Swapnil Bhondwe, Aniket Parbat (Nagpur), Harish Tayde, Vinay Sharma, Anvar Ansari (Akola), Pravin Lande, Ratnakar Pachare, Pravin Durbade, Sandeep Aade, Chandrashekhar Khoke, and Amar Pachare (Rajura, Chandrapur) helped in various ways.

\section{Literature Cited}

Adimallaah, D. and A. Vyas. 2015. Cases of albinism in Russel's Viper Daboia russelii from Mumbai, Maharashtra, India. Reptile Rap 17: 25-26.

Basu, D., S. Srivastava, and S.P. Singh. 2003. A case of albinism in Kachuga tentoria circumdata (Testudines: Bataguridae). Hamadryad 27: 254.

Bechtel, H.B. 1995. Reptile and Amphibian Variants: Colors, Patterns and Scales. Krieger Publishing Company, Malabar, Florida, USA.

Bechtel, H.B. and E. Bechtel. 1981. Albinism in the snake, Elaphe obsoleta. Journal of Herpetology 15: 397-402.

Bhutkar, R. and A. Mahabal. 2014. Cases of albinism in snakes from Maharashtra, India. Reptile Rap 16: 31-35.

Broghammer, S. 2000. Albinos, Color and Pattern Mutations of Snakes and Other Reptiles. M\&S Verlag, Münster, Germany.

Creel, D.J., C.G. Summers, and R.A. King. 1990. Visual anomalies associated with albinism. Ophthalmic Paediatrics and Genetics 11: 193-200.

Cyril, R.K. 2009. Record of albino Indian Flapshell Turtle (Lissemys punctata) from Adyar Wetland, South India. Cobra 3(2): 10-11.

Daniel, J.C. 2002. The Book of Indian Reptiles and Amphibians. Bombay Natural History Society, Mumbai, India.

Das, I. 2002. A Photographic Guide to Snakes and Other Reptiles of India. New Holland Publishers Ltd., London, UK.
Deshmukh, R.V., S.A. Deshmukh, and S.A. Badhekar. 2015. Rescued records of snakes from Nagpur District, Maharashtra with data on unrecorded species. Reptile Rap 17: 34-43.

Hoshing, V., S. Thakur, and A. Mahabal. 2013. Cases of total albinism in Green Keelback Macropisthodon plumbicolor and Common Wolf Snake Lycodon aulicus (Colubridae). Reptile Rap 15: 46-47.

Jadhav, M., A. Mahabal, V. Desai, and S. Jatin. 2014. A case of total albinism in Common Kukri Snake Oligodon arnensis (Colubridae) with an unusual colour pattern. Reptile Rap 16: 3-5.

Krecsák, L. 2008. Albinism and leucism among European Viperinae: A review. Russian Journal of Herpetology 15: 97-102.

Kumar, R. 1988. The albino cobra. Environment Today 3 (1\&2): 6-8.

Kumbar, S.M., A.B. Ghadage, S.S. Patil, and S.B. Lad. 2016. Record of albino sand boa (Gongylophis conicus) from Sangli District, western Maharashtra, India. Russian Journal of Herpetology 23: 70-72.

Lahiri, P.K. 1955. A white python. Journal of the Bombay Natural History Society 53: 135-136.

Mahabal A. and S. Thakur. 2014. Instances of aberrant colors and patterns among the Indian herpetofauna: A review. Russian Journal of Herpetology 21: 80-88.

Nande, R. and R. Deshmukh. 2007. Snakes of Amaravati District including Melghat, Maharashtra, with important records of the Indian egg eater, montane trinket snake and Indian smooth snake. Zoos' Print Journal 22: 2920-2924.

Roulin, A. and P. Bize. 2006. Sexual selection in genetic colour-polymorphic species: a review of experimental studies and perspectives. Journal of Ethology 25: 99-105.

Sayyed, A. 2012. The distribution of albino Green Keelback. <http:www. indiawilds.comdiary_the-distribution-of-albino-greenkeelback $>$.

Sharma, R.C. 2007. The Fauna of India and the Adjacent Countries. Reptilia. Volume III. Serpentes. Zoological Survey of India, Kolkata, India.

Smith, M.A. 1943. The Fauna of British India, Ceylon and Burma, Including the Whole of the Indo-Chinese Sub-region. Reptilia and Amphibia. Volume IIISerpentes. Taylor and Francis, London. 
Sweet, S.S. 1985. Geographic variation, convergent crypsis and mimicry in Gopher Snakes (Pituophis melanoleucus) and Western Rattlesnakes (Crotalus viridis). Journal of Herpetology 19: 44-67.

Thakur, M. and K. Trivedi. 2018. Albinism in snakes rescued in Surat, India. Reptiles \& Amphibians 25: 63-67.

Vyas, R. 2012. Albinism in two Indian colubrine snakes, Oligodon arnensis and Coelognathus helena. Sauria 34(3): 57-61.

Vyas, R. 2013. Notes on an unusual colour morphism in oriental rat snake Ptyas mucosa (Linnaeus, 1758). Reptile Rap 15: 43-45.

Vyas, R., V. Prajapati, and D. Parmar. 2012. The case of incomplete albinism in Indian Red Sand Boa Eryx johnii johnii (Russell, 1801) (Reptilia: Serpentes: Boidae). Russian Journal of Herpetology 19: 299-302.

Whitaker, R. 1971. Notes of Indian snakes. 1. Journal of the Bombay Natural History Society 68: 461-463.

Whitaker, R. and A. Captain. 2004. Snakes of India. The Field Guide. Draco Books, Chennai, India. 